\title{
Epidemiology of traumatic brain injury in Europe
}

\author{
Wouter Peeters ${ }^{1} \cdot$ Ruben van den Brande $^{1} \cdot$ Suzanne Polinder $^{2} \cdot$ Alexandra Brazinova $^{3}$. \\ Ewout W. Steyerberg ${ }^{2}$ - Hester F. Lingsma ${ }^{2}$ - Andrew I. R. Maas ${ }^{1,4}$
}

Received: 27 April 2015 / Accepted: 14 July 2015 / Published online: 14 August 2015

(C) The Author(s) 2015. This article is published with open access at Springerlink.com

\begin{abstract}
Background Traumatic brain injury (TBI) is a critical public health and socio-economic problem throughout the world, making epidemiological monitoring of incidence, prevalence and outcome of TBI necessary. We aimed to describe the epidemiology of traumatic brain injury in Europe and to evaluate the methodology of incidence studies.

Method We performed a systematic review and meta-analyses of articles describing the epidemiology of TBI in European countries. A search was conducted in the PubMed electronic database using the terms: epidemiology, incidence, brain injur*, head injur* and Europe. Only articles published in English and reporting on data collected in Europe between 1990 and 2014 were included.

Results In total, 28 epidemiological studies on TBI from 16 European countries were identified in the literature. A great variation was found in case definitions and case ascertainment between studies. Falls and road traffic accidents (RTA) were the two most frequent causes of TBI, with falls being reported more frequently than RTA. In most of the studies a peak TBI
\end{abstract}

Electronic supplementary material The online version of this article (doi:10.1007/s00701-015-2512-7) contains supplementary material, which is available to authorised users.

Andrew I. R. Maas

andrew.maas@uza.be

1 University of Antwerp, Antwerp, Belgium

2 Department of Public Health, Centre for Medical Decision Making, Erasmus MC, Rotterdam, The Netherlands

3 Faculty of Health Sciences and Social Work, Trnava University, Trnava, Slovak Republic

4 Department of Neurosurgery, Antwerp University Hospital, Wilrijkstraat 10, 2650 Edegem, Belgium incidence was seen in the oldest age groups. In the meta-analysis, an overall incidence rate of 262 per 100,000 for admitted TBI was derived.

Conclusions Interpretation of published epidemiologic studies is confounded by differences in inclusion criteria and case ascertainment. Nevertheless, changes in epidemiological patterns are found: falls are now the most common cause of TBI, most notably in elderly patients. Improvement of the quality of standardised data collection for TBI is mandatory for reliable monitoring of epidemiological trends and to inform appropriate targeting of prevention campaigns.

Keywords Epidemiology · Traumatic brain injury · Systematic review $\cdot$ Incidence $\cdot$ External cause $\cdot$ Mortality

\section{Introduction}

Traumatic brain injury (TBI) constitutes a major health and socioeconomic problem throughout the world $[6,9]$. It is prevalent in both low- and high-income countries and affects people of all ages. TBI is called the 'silent epidemic' because problems resulting from TBI are often not immediately visible, and TBI patients are not very vociferous. The term 'silent' further reflects the common underestimation of the actual incidence and that society is often unaware of the impact of TBI [14]. Epidemiological studies of TBI are essential to the targeted prevention and effective treatment of brain-injured patients.

Epidemiological studies are, however, often confounded by a general lack of clear definitions for TBI. A clear, concise definition of TBI is essential in the attempt to understand the epidemiology.

'Traumatic brain injury' has replaced the former term 'head injury' as it better captures the importance of the 'brain' [28]. 
TBI was recently defined as: 'An alteration in brain function, or other evidence of brain pathology, caused by an external force' [23].

Tagliaferri et al. [38] conducted a systematic review on the epidemiology of TBI in Europe in 2006. In their review they analysed 23 studies published between 1980 and 2003. An aggregated (i.e. fatal plus hospitalised) incidence rate of 235 cases per 100,000 people per year, an average mortality rate of 15 per 100,000 people per year and a case fatality rate of $2.7 \%$ were calculated.

In the past decade, new insights into the epidemiology of TBI have emerged. Epidemiological patterns appear to be changing with an increasing incidence of TBI in the elderly. Various reports claim that mortality in TBI is decreasing [8, 15]. The purpose of this systematic review is to provide a contemporary overview of epidemiology of TBI in Europe with a specific focus on epidemiological patterns and on the methodological quality of epidemiologic studies.

\section{Methods}

A search was conducted in the PubMed electronic database using the following search-terms: epidemiology, incidence, brain injur*, head injur* and Europe. Reference lists of review studies and articles included in the review were screened for titles that included the key terms.

\section{Inclusion criteria}

Studies were included if they met the following inclusion criteria: (1) published in English in the period 1990-2014 with a full text available; (2) original study; (3) predominantly focusing on the epidemiology of TBI; (4) predominantly focusing on TBI, not on the more general head injury; (5) focusing on the population as a whole, not only on a specific subgroup (e.g. cyclists, rugby players, children, etc.); (6) study period at least 1 year; (7) only including data from 1990 or later; (8) not only focusing on mild TBI; (9) if multiple publications used the same study population, the most recent report was used, as it generally addressed a larger population.

\section{Data extraction}

Relevant papers were selected by screening the titles (first step), abstracts (second step) and entire articles (third step), retrieved through the database searches. During each step the title, abstract or entire article was screened to ensure that it met the inclusion criteria. This screening was conducted independently by two researchers (W.P. and R.v.d.B.). Extracted data included source population, study period, study group size, case ascertainment, case criteria, incidence, age distribution, sex distribution, mortality and most frequent cause of TBI.

\section{Methodological quality}

Characteristics and methodological quality of selected studies were evaluated with a particular focus on study design, case ascertainment, case definition, patient population and the description of the methodology. We based the evaluation of methodological quality on five elements of the STROBE checklist [39] which were most relevant to the quality of reported incidence and mortality rates: study design, setting, participants, data sources/measurement and study size.

\section{Data and statistical analysis}

Data are reported as in the original manuscripts. For calculation of an overall incidence rate in the meta-analysis, we used random effects modelling to address heterogeneity between the studies. Heterogeneity was expressed by the $\tau^{2}$ and $I^{2}$ statistics. Tau-squared

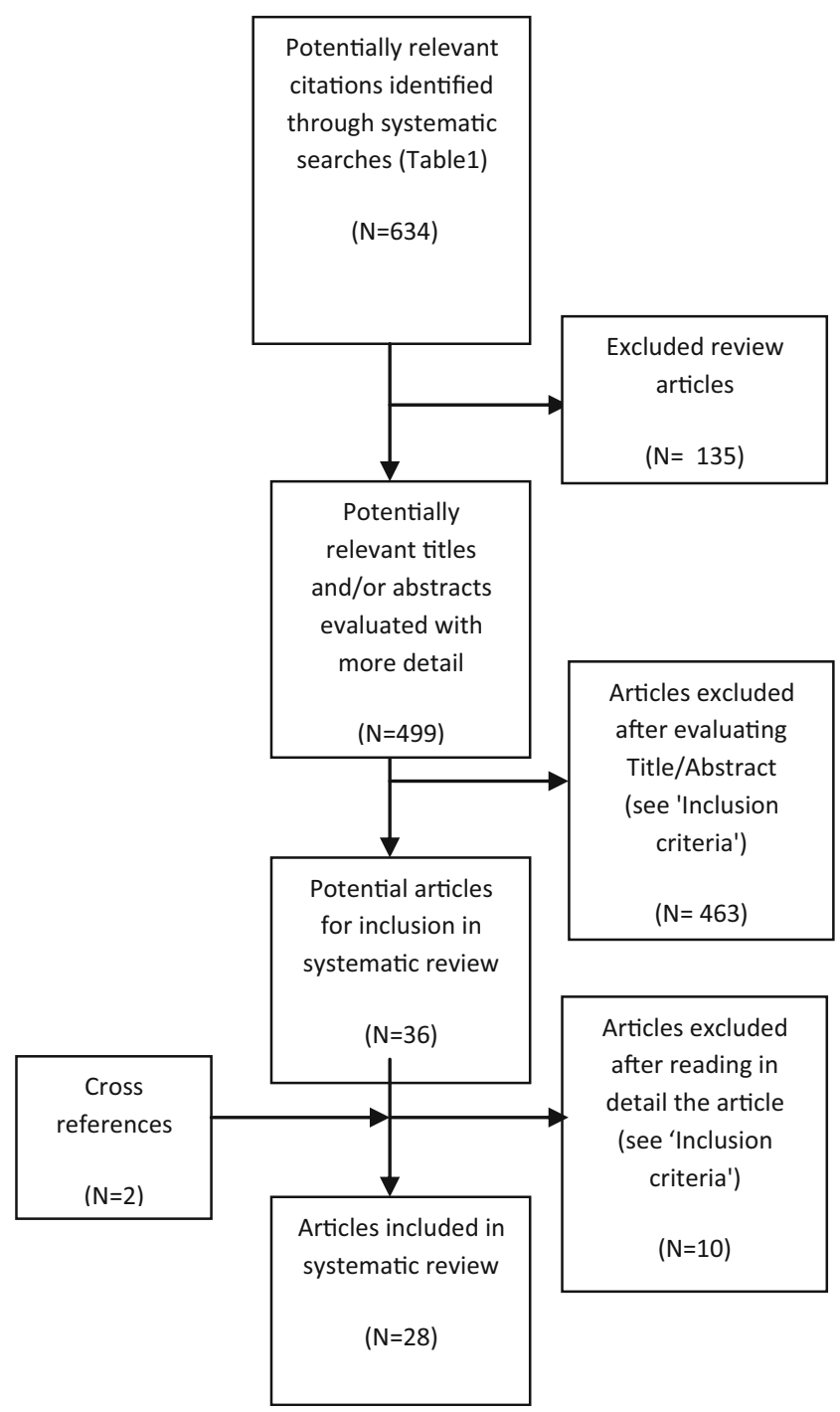

Fig. 1 Flow diagram of the literature search and selection of articles 
Table 1 Study characteristics and quality assessment

\begin{tabular}{|c|c|c|c|c|}
\hline Reference & Source Population & $\begin{array}{l}\text { Study duration } \\
\text { and period }\end{array}$ & $\begin{array}{l}\text { Study group size (included } \\
\text { patients/source population) }\end{array}$ & $\begin{array}{l}5 \text { STROBE quality } \\
\text { criteria }\end{array}$ \\
\hline $\begin{array}{l}\text { Andelic et al. } \\
\qquad(2008)[2]\end{array}$ & Population of city Oslo, Norway & $\begin{array}{l}1 \text { year }(15 \\
\quad \text { May 2005- } \\
14 \text { May 2006) }\end{array}$ & $445 / 543,129$ & Complete \\
\hline $\begin{array}{l}\text { Andelic et al. } \\
\text { (2012) [1] }\end{array}$ & Population of Norway & $\begin{array}{l}2 \text { years }(2009- \\
2010)\end{array}$ & $359 / 2,143,661$ & Complete \\
\hline $\begin{array}{l}\text { Andersson } \\
\text { et al. } \\
\text { (2003) [3] }\end{array}$ & Population based data from region of Western Sweden & $\begin{array}{l}1 \text { year (April } \\
\text { 1992-April } \\
\text { 1993) }\end{array}$ & $753 / 138,000$ & Complete \\
\hline $\begin{array}{l}\text { Andriessen } \\
\text { et al. } \\
\text { (2011) [4] }\end{array}$ & $\begin{array}{l}\text { Case series: adults ( }>16 \text { years) admitted to one of the } 5 \\
\text { participating specialised trauma centres in The } \\
\text { Netherlands }\end{array}$ & $\begin{array}{l}1 \text { year } \\
\text { (June 2008- } \\
\text { May 2009) }\end{array}$ & $508 /$ not reported & $\begin{array}{l}\text { Incomplete: } \\
\text { participants }\end{array}$ \\
\hline $\begin{array}{l}\text { Baldo et al. } \\
\text { (2003) [5] }\end{array}$ & Residents of the Veneto Region of Northeast Italy & $\begin{array}{l}5 \text { years }(1996- \\
2000)\end{array}$ & $55,368 / 4,480,000$ & Complete \\
\hline $\begin{array}{l}\text { Firsching \& } \\
\text { Woischne- } \\
\text { ck (2001) } \\
\text { [7] }\end{array}$ & Population of Germany & 1 year $(1996)$ & $280,000 / 82,000,000$ & $\begin{array}{l}\text { Incomplete: study } \\
\text { design, participants }\end{array}$ \\
\hline $\begin{array}{l}\text { Heskestad } \\
\quad \text { et al. } \\
\text { (2009) [10] }\end{array}$ & Residents of the Stavanger Region, Norway & 1 year $(2003)$ & $585 / 283,317$ & Complete \\
\hline $\begin{array}{l}\text { Ingebritsen } \\
\quad \text { et al. } \\
\quad(1998)[12]\end{array}$ & $\begin{array}{l}\text { Population of city of Tromsø, Norway and } 16 \text { surrounding } \\
\text { municipalities }\end{array}$ & 1 year $(1993)$ & $247 / 108,017$ & Complete \\
\hline $\begin{array}{l}\text { Katsaragakis } \\
\text { et al. } \\
\quad(2010)[13]\end{array}$ & $\begin{array}{l}\text { Case series: patients of } 30 \text { hospitals in Greece. Hospitals } \\
\text { not reported. }\end{array}$ & $\begin{array}{l}1 \text { year (year not } \\
\text { reported) }\end{array}$ & $3,383 /$ not reported & $\begin{array}{l}\text { Incomplete: setting, } \\
\text { participants, data } \\
\text { sources/ } \\
\text { measurement }\end{array}$ \\
\hline $\begin{array}{l}\text { Koskinen \& } \\
\quad \text { Alaranta } \\
\text { (2008) [14] }\end{array}$ & All residents of Finland & $\begin{array}{l}15 \text { years }(1991- \\
2005)\end{array}$ & $\begin{array}{l}77,959 / 5,010,000(1991)- \\
5,250,000(2005)\end{array}$ & Complete \\
\hline $\begin{array}{l}\text { Maegele et al. } \\
\text { (2007) [18] }\end{array}$ & Residents of the Cologne area, Germany & $\begin{array}{l}10 \text { years }(1990- \\
1999)\end{array}$ & $731 / 1,000,000$ & Complete \\
\hline $\begin{array}{l}\text { Masson et al. } \\
\text { (2001) [19] }\end{array}$ & Population of Aquitaine, France & 1 year $(1996)$ & $325 / 2,800,000$ & Complete \\
\hline $\begin{array}{l}\text { Masson et al. } \\
\text { (2003) [20] }\end{array}$ & Population of Aquitaine, France & 1 year (1996) & $497 / 2,800,000$ & Complete \\
\hline $\begin{array}{l}\text { Mauritz et al. } \\
\text { (2008) [22] }\end{array}$ & $\begin{array}{l}\text { European Regions with different economic status (Austria } \\
\text { ['high income'], Solvakia and Croatia ['upper middle } \\
\text { income'], Macedonia and Bosnia ['lower middle } \\
\text { income']) }\end{array}$ & $\begin{array}{l}4.5 \text { years } \\
\text { (January } \\
\text { 2001- } \\
\text { June 2005) }\end{array}$ & $1,172 /$ not reported & Complete \\
\hline $\begin{array}{l}\text { Mauritz et al. } \\
\text { (2014) [21] }\end{array}$ & All Austrian residents & $\begin{array}{l}3 \text { years }(2009- \\
2011)\end{array}$ & $74,744 / 8,443,018$ & Complete \\
\hline $\begin{array}{l}\text { Numminen } \\
\quad(2010)[24]\end{array}$ & Population based data from region of South East Finland & $\begin{array}{l}2 \text { years (April } \\
\text { 2002- } \\
\text { March 2004) }\end{array}$ & $370 / 83,900$ & Complete \\
\hline $\begin{array}{l}\text { Pérez et al. } \\
\text { (2012) [25] }\end{array}$ & Residents of Spain, 2000-2009 & $\begin{array}{l}10 \text { years }(2000- \\
2009)\end{array}$ & $206,503 /$ not reported & Incomplete: study size \\
\hline $\begin{array}{l}\text { Puljula et al. } \\
\text { (2013) [26] }\end{array}$ & $\begin{array}{l}\text { All residents of Northern Ostrobothnia, Finland, } 1999 \text { and } \\
2007\end{array}$ & $\begin{array}{l}2 \text { years }(1999 \& \\
\text { 2007) }\end{array}$ & $\begin{array}{l}126(1999)-135(2007) / \\
369,827(1999)-390,038 \\
(2007)\end{array}$ & Complete \\
\hline $\begin{array}{l}\text { Rickels et al. } \\
\quad(2010)[27]\end{array}$ & Residents in regions of Hannover and Münster, Germany & $\begin{array}{l}1 \text { year } \\
\text { (March 2000- } \\
\text { Februari } \\
\text { 2001) }\end{array}$ & $6,783 / 2,200,000$ & Complete \\
\hline $\begin{array}{l}\text { Rosso et al. } \\
\quad \text { (2007) [29] }\end{array}$ & $\begin{array}{l}\text { Case series: patients from five centres (Graz, Klagenfurt, } \\
\text { Linz, Salzburg, Vienna) in Austria }\end{array}$ & $\begin{array}{l}3 \text { years } \\
\text { (between } \\
1999 \text { and } \\
2004 \text { ) }\end{array}$ & 492/not reported & Complete \\
\hline
\end{tabular}


Table 1 (continued)

\begin{tabular}{|c|c|c|c|c|}
\hline Reference & Source Population & $\begin{array}{l}\text { Study duration } \\
\text { and period }\end{array}$ & $\begin{array}{l}\text { Study group size (included } \\
\text { patients/source population) }\end{array}$ & $\begin{array}{l}5 \text { STROBE quality } \\
\text { criteria }\end{array}$ \\
\hline $\begin{array}{l}\text { Scholten et al. } \\
\text { (2014) [30] }\end{array}$ & Population of The Netherlands & $\begin{array}{l}3 \text { years }(2010- \\
2012)\end{array}$ & $\begin{array}{l}\text { 3,762/not reported (study); } \\
\text { 34,681/not reported } \\
\text { (national estimate) }\end{array}$ & $\begin{array}{l}\text { Incomplete: setting, } \\
\text { study size }\end{array}$ \\
\hline $\begin{array}{l}\text { Servadei et al. } \\
\text { (2002) [31] }\end{array}$ & Residents of the Romagna Region of Italy & 1 year $(1996)$ & $2,430 / 970,000$ & Complete \\
\hline $\begin{array}{l}\text { Servadei et al. } \\
\text { (2002) [32] }\end{array}$ & Residents in regions of Trentino and Romagna, Italy & 1 year $(1998)$ & $\begin{array}{l}1,562 \text { (Trentino)-2,880 } \\
\text { (Romagna)/470,000 } \\
\text { (Trentino)-970,000 } \\
\text { (Romagna) }\end{array}$ & Complete \\
\hline $\begin{array}{l}\text { Shivaji et al. } \\
\text { (2014) [33] }\end{array}$ & Population of Scotland & $\begin{array}{l}12 \text { years }(1998- \\
2009)\end{array}$ & $208,195 /$ not reported & Incomplete: study size \\
\hline $\begin{array}{l}\text { Steudel et al. } \\
\text { (2005) [34] }\end{array}$ & Total German population & 1 year $(1998)$ & $276,584 / 82,037,100$ & Complete \\
\hline $\begin{array}{l}\text { Stocchetti } \\
\text { et al. } \\
\text { (2012) [35] }\end{array}$ & $\begin{array}{l}\text { Patients admitted to three neurosurgical ICUs in Milan and } \\
\text { Monza, Italy, 1997-2007 }\end{array}$ & $\begin{array}{l}11 \text { years } \\
\text { (January } \\
\text { 1997- } \\
\text { December } \\
\text { 2007) }\end{array}$ & $1,366 /$ not reported & $\begin{array}{l}\text { Incomplete: } \\
\text { participants }\end{array}$ \\
\hline $\begin{array}{l}\text { Styrke et al. } \\
\text { (2007) [36] }\end{array}$ & Population-based data from region of Northern Sweden & 1 year $(2001)$ & $449 / 137,000$ & Incomplete: setting \\
\hline $\begin{array}{l}\text { Szarpak \& } \\
\quad \text { Madziala } \\
\quad(2011)[37]\end{array}$ & Residents of the Piaseczno and Otwock Counties, Poland & 1 year $(2009)$ & $1,049 /$ not reported & $\begin{array}{l}\text { Incomplete: setting, } \\
\text { participants, study } \\
\text { size }\end{array}$ \\
\hline
\end{tabular}

represents the estimate of the between-study variants in a random effects meta-analysis. A $\tau^{2}>1$ suggests the presence of substantial statistical heterogeneity. $I^{2}$ represents the percentage of the total variation across studies due to heterogeneity [11]. Comprehensive Meta-Analysis (CMA) software was used for the calculations.

\section{Results}

The PubMed search identified 743 articles; 109 duplicates were removed, resulting in 634 potentially relevant citations (see ESM 1). Following the screening of titles, abstracts and entire articles, a total of 28 articles were retained for inclusion in this systematic review (Fig. 1).

\section{Study characteristics}

Eight reports were of national populations (Austria, Finland, Germany [2×], Norway, Scotland, Spain and Netherlands). One study compared the epidemiology of TBI between regions of different European countries [22]. Nineteen focused on regions, counties or provinces of one European country. Altogether we found data from sixteen different countries: Norway, Sweden, Netherlands, Italy, Germany, Greece, Finland, France, Austria, Slovak Republic, Croatia, Macedonia, Bosnia, Poland and Scotland.
Fifteen out of the 28 studies had a study period of exactly 1 year, five studies [14, 18, 25, 33, 35] had a study period of 10 years or more. The number of included patients ranged from 247 [12] to 280,000 [7], the size of the total source population from 83,900 [24] to $82,037,100$ [34]. Nine studies did not report their source population size. Characteristics of the included studies and results of quality assessment are presented in Table 1.

\section{Methodological quality and incidence}

A total of 19 studies met the five selected STROBE criteria. Nine studies did not meet all five criteria, of which two failed on two criteria and a further 2 on three criteria (Table 1). Table 2 summarises details of inclusion criteria, case definitions, severity assessment and reported/calculated incidence rates per year of the selected studies. A large variation was found in inclusion criteria, case ascertainment and case definitions. Eight studies were based on hospital admissions, six on emergency department admissions and four on a combination of both. Other sources used for case ascertainment were death certificates, ICU admissions, hospital discharges, pre-hospital emergencies, or a combination of these. We also found large differences in the case criteria that were used in the studies. Seven studies used ICD-10 codes to define TBI, seven used ICD-9 codes and another two used both. Five studies used 
Table 2 Inclusion criteria and incidence rate

\begin{tabular}{|c|c|c|c|c|}
\hline Reference & $\begin{array}{l}\text { Inclusion criteria and case } \\
\text { ascertainment }\end{array}$ & Case definitions & TBI severity & Incidence rate/year \\
\hline $\begin{array}{l}\text { Andelic } \\
\text { et al. } \\
\text { (2008) [2] }\end{array}$ & $\begin{array}{l}\text { Persons residing in Oslo at the time } \\
\text { of injury, hospitalised with acute } \\
\text { TBI, during the period 2005- } \\
2006 \text {. }\end{array}$ & $\begin{array}{l}\text { ICD-10 codes: S02.0-S02.9, S06.0- } \\
\text { S06.9, S07.0, S07.1, S07.8, } \\
\text { S07.9, S09.7-S09.9, T04 and } \\
\text { T06. Excluded: isolated injuries } \\
\text { to scalp, isolated facial and jaw } \\
\text { fractures, anoxia, birth trauma, } \\
\text { patients not living in Oslo, } \\
\text { patients with subdural } \\
\text { haematomas, with multiple } \\
\text { admissions for same injury and } \\
\text { patients admitted later than } 48 \mathrm{~h} \\
\text { after the trauma. }\end{array}$ & $\begin{array}{l}\text { GCS: } 86 \% \text { mild, } \\
7.9 \% \text { moderate, } \\
6.1 \% \text { severe }\end{array}$ & $83.3 / 105$ \\
\hline $\begin{array}{l}\text { Andelic } \\
\text { et al. } \\
\text { (2012) [1] }\end{array}$ & $\begin{array}{l}\text { All adults ( }>16 \text { years old) residing } \\
\text { in Norway with severe TBI } \\
\text { admitted within } 72 \mathrm{~h} \text { after injury } \\
\text { to a Norwegian Trauma Referral } \\
\text { Centres during the 2-year period. }\end{array}$ & $\begin{array}{l}\text { ICD-10 codes S06.0-S06.9. Severe } \\
\text { TBI was defined as lowest } \\
\text { unsedated GCS Score } \leq 8 \text { during } \\
\text { the first } 24 \mathrm{~h} \text { after injury. }\end{array}$ & GCS: $100 \%$ severe & $\begin{array}{l}\text { 5.2/ } 105(2009) 4.1 / \\
105(2010) \text { (Overall } \\
\text { age-adjusted } \\
\text { incidence rate) }\end{array}$ \\
\hline $\begin{array}{l}\text { Andersson } \\
\text { et al. } \\
\text { (2003) [3] }\end{array}$ & $\begin{array}{l}\text { Patients attending hospital } \\
\text { emergency unit, discharge } \\
\text { register, regional neurosurgical } \\
\text { clinic and coroner's records. }\end{array}$ & $\begin{array}{l}\text { ICD-9 codes } 850-854,800-804 \\
\text { plus mix of clinical symptoms or } \\
\text { signs as defined by American } \\
\text { Congress of Rehabilitation } \\
\text { Medicine for TBI severity. }\end{array}$ & $\begin{array}{l}\text { ACRM criteria: } 97.5 \% \text { mild, } \\
2.5 \% \text { moderate-to-severe }\end{array}$ & $546 / 105$ \\
\hline $\begin{array}{l}\text { Andriessen } \\
\text { et al. } \\
\text { (2011) [4] }\end{array}$ & $\begin{array}{l}\text { Patients with TBI admitted to } \\
\text { emergency department of one of } \\
\text { the trauma centres. }\end{array}$ & $\begin{array}{l}\text { Patients with TBI and an ED } \\
\text { admission GCS score } \leq 13 \text {. TBI } \\
\text { not further defined. Exclusion } \\
\text { criteria: age }<16 \text { years and } \\
\text { hospital admission }>72 \text { h after } \\
\text { injury. }\end{array}$ & $\begin{array}{l}\text { GCS: } 34 \% \text { moderate, } \\
67 \% \text { severe }\end{array}$ & Not reported \\
\hline $\begin{array}{l}\text { Baldo et al. } \\
\text { (2003) [5] }\end{array}$ & $\begin{array}{l}\text { All hospital discharge records } \\
\text { containing ICD-9-CM codes: } \\
\text { 800.0-801.9, 803.0-804.9, } \\
\text { 850.0-854.1. }\end{array}$ & $\begin{array}{l}\text { Brain injury defined by discharge } \\
\text { ICD codes and only cases } \\
\text { hospitalised. }\end{array}$ & $\begin{array}{l}\text { ICD/AIS: } 1996=45 \% \text { mild, } \\
14 \% \text { moderate, } 6 \% \text { severe, } \\
35 \% \text { unknown; } 1998=43 \% \\
\text { mild, } 16 \% \text { moderate, } 7 \% \\
\text { severe, } 33 \% \text { unknown; } \\
2000=53 \% \text { mild, } 13 \% \\
\text { moderate, } 18 \% \text { severe, } \\
16 \% \text { unknown }\end{array}$ & $\begin{array}{l}301 / 105(1996) 249 / \\
105(1998) 212 / 105 \\
(2000)(29.4 \% \\
\text { decrease from } 1996 \\
\text { to 2000) }\end{array}$ \\
\hline $\begin{array}{l}\text { Firsching \& } \\
\text { Woischn- } \\
\text { eck } \\
\text { (2001) [7] }\end{array}$ & $\begin{array}{l}\text { Data from death certificates, Federal } \\
\text { Board of Statistics (Hospital } \\
\text { discharge reports). }\end{array}$ & $\begin{array}{l}\text { ICD-9 codes (not reported) for } \\
\text { hospital admitted persons. }\end{array}$ & $73 \%$ mild & $\begin{array}{l}350 / 105 \text { (overall) 247/ } \\
105 \text { (mild) with } \\
\text { intracranial } \\
\text { lesions }=29 / 105 \\
\text { with skull } \\
\text { fractures }=21 / 105\end{array}$ \\
\hline $\begin{array}{l}\text { Heskestad } \\
\quad \text { et al. } \\
\text { (2009) }\end{array}$ & $\begin{array}{l}\text { All head-injured patients }(n=585) \\
\text { referred to any department at the } \\
\text { University Hospital of Stavanger }\end{array}$ & $\begin{array}{l}\text { ICD-10 codes S00 through S09 } \\
\text { with subgroups. Head injury was } \\
\text { defined as physical damage to the }\end{array}$ & $\begin{array}{l}\text { HISS: } 26 \% \text { minimal, } \\
58 \% \text { mild, } 3 \% \text { moderate, } \\
13 \% \text { severe }\end{array}$ & $\begin{array}{l}207 / 105 \text { (overall) } \\
\text { hospital admission } \\
\text { rate of } 157 / 105\end{array}$ \\
\hline
\end{tabular}

Ingebritsen All head-injured patients referred

et al.

(1998)

[12] first to University Hospital or admitted to any hospital department plus emergency department treated and discharged.

Katsaragakis Trauma patients that required et al. admission, transfer to a higher (2010) level unit or arrived dead or died [13] in the emergency department and had had at least one brain injury. brain or skull caused by external force. Isolated injuries to the scalp, face or cervical spine and patients with birth injuries were excluded.

Head injury defined as physical damage to the brain or skull by external force and GCS and Head Injury Severity Scale.

Brain injury not defined.
229/105 (overall) hospital admission rate of $169 / 105$
HISS: $32 \%$ minimal, $49 \%$ mild

Not reported
Not reported 
Table 2 (continued)

\begin{tabular}{|c|c|c|c|c|}
\hline Reference & $\begin{array}{l}\text { Inclusion criteria and case } \\
\text { ascertainment }\end{array}$ & Case definitions & TBI severity & Incidence rate/year \\
\hline $\begin{array}{l}\text { Koskinen \& } \\
\quad \text { Alaranta } \\
\text { (2008) } \\
{[14]}\end{array}$ & $\begin{array}{l}\text { Hospital Discharge register of the } \\
\text { Finnish National Research } \\
\text { Development Centre for Welfare } \\
\text { and Health for entire } 5.1 \text { million } \\
\text { population. }\end{array}$ & $\begin{array}{l}\text { ICD-9 codes } 800-801,803,850- \\
\text { 854, first time admissions during } \\
\text { 1991-96. ICD-10 codes S02.0, } \\
\text { S02.00, S02.01, S02.1, S02.10, } \\
\text { S02.11, S02.7, S02.70, S02.71, } \\
\text { S02.8, S02.80, S02.81, S02.9, } \\
\text { S02.90, S02.91, T020, S06.0, } \\
\text { S06.1-9, first time admissions } \\
\text { during 1997-2005. }\end{array}$ & Not reported & $\begin{array}{l}97 / 105(1991-1995) \\
102 / 105(1996- \\
2000) 104 / 105 \\
(2001-2005)\end{array}$ \\
\hline $\begin{array}{l}\text { Maegele } \\
\text { et al. } \\
\quad(2007) \\
{[18]}\end{array}$ & $\begin{array}{l}\text { 130,000 pre-hospital emergencies } \\
\text { were screened for TBI. }\end{array}$ & $\begin{array}{l}\text { Patients with a pre-hospital GCS } \\
\text { score } \leq 8 \text { and/or AIS head score } \\
\geq 2 \text { with confirmed TBI via } \\
\text { appropriate diagnostic tests (e.g. } \\
\text { CT). }\end{array}$ & GCS/AIS head: $100 \%$ severe & $7.3 / 105$ \\
\hline $\begin{array}{l}\text { Masson } \\
\text { et al. } \\
(2001) \\
{[19]}\end{array}$ & $\begin{array}{l}\text { Persons admitted to hospital via an } \\
\text { emergency service with } \\
\text { diagnosis of severe brain injury } \\
\text { during } 1996 \text {. }\end{array}$ & $\begin{array}{l}\text { Severe brain injury defined by AIS } \\
\text { score of } 4 \text { or } 5 \text { to head region. }\end{array}$ & GCS: $100 \%$ severe & $\begin{array}{l}\text { 17.3/105 (overall) } 7.2 / \\
105(\text { AIS head } 4) \\
\text { 10.1/105 (AIS head } \\
5)\end{array}$ \\
\hline $\begin{array}{l}\text { Masson } \\
\text { et al. }\end{array}$ & $\begin{array}{l}\text { Patients admitted to any one of } 19 \\
\text { public hospitals with prolonged }\end{array}$ & $\begin{array}{l}\text { Persons with prolonged coma or } \\
\text { significant intra-cranial injury }\end{array}$ & AIS head: $100 \%$ severe & $\begin{array}{l}8.5 / 105(248 \text { patients } \\
\text { registered })\end{array}$ \\
\hline
\end{tabular}

(2003) $\quad$ public hospitals with prolonged

[20]

with coma $>24 \mathrm{~h}$ : coma

determined from GCS of 8 or less

before sedation.

Mauritz Patients with severe TBI admitted to

et al. one of the 13 tertiary-care-level

(2008) centres.

[22]

Mauritz

et al.

(2014)

[21]

Data on all hospital discharges, outpatients and in-hospital deaths due to TBI were collected from various sources (Statistik Austria, AUVA).

Numminen All cases ( $>14$ years) with (2011) symptoms of brain injury after

[24] head trauma were collected from the health centres in the area covering three municipalities (Imatra, Joutenso and Lappeenranta) and from the one hospital (South Karelia Central Hospital) taking care of all corresponding TBI cases. Also death certificates were collected.

Pérez et al. National Hospital Discharge (2012) Register.

[25]

Puljula et al. Patients with moderate-to-severe (2013) TBI who were admitted to the ER [26] of Oulo University Hospital, plus

Emergency admissions with ICD-9 codes: $800,801,803,804,850$ 854. Programmed and readmissions were excluded.

Moderate-to-severe TBI defined as GCS $\leq 12$.
ISS: $41.1 \%$ moderate, $26.8 \%$ serious, $32.2 \%$ severe

GCS: $100 \%$ moderate-to-severe those who succumbed from TBI outside the hospital. Only residents of Northern Ostrobothnia were included. defined by the US National

Traumatic Coma Database: GCS $\leq 8$ within 48 h of injury.

codes S06.0-S06.9, T68, or T07;

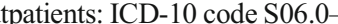

10 codes S01.0-S01.9, S02.0,

T90.1, T90.2, or T90.4-T90.9. main or immediate cause of death was an ICD-10 code of S06 or S07 were included.

Not reported

$303 / 105$

GCS/CT: $71 \%$ mild, $29 \%$ severe $\quad 221 / 105$ mild TBI in

$71 \%$ of patients
47.3/105 (during the 9year study period the incidence rate presents a reduction of $23.8 \%$ )

$34 / 105$ (1999) 35/ 105 (2007) 
Table 2 (continued)

\begin{tabular}{|c|c|c|c|c|}
\hline Reference & $\begin{array}{l}\text { Inclusion criteria and case } \\
\text { ascertainment }\end{array}$ & Case definitions & TBI severity & Incidence rate/year \\
\hline $\begin{array}{l}\text { Rickels et al. } \\
\qquad(2010) \\
{[27]}\end{array}$ & $\begin{array}{l}\text { Patients admitted to hospital } \\
\text { emergency department in the } \\
\text { regions due to an acute head } \\
\text { injury with involvement of the } \\
\text { brain. }\end{array}$ & $\begin{array}{l}\text { At least one of the following } \\
\text { symptoms or ICD-10 diagnosis } \\
\text { codes: Symptoms: nausea or } \\
\text { vomiting, headache, loss of } \\
\text { consciousness with anterograde/ } \\
\text { retrograde amnesia, impaired } \\
\text { consciousness or impaired } \\
\text { vigilance, fracture of face and/or } \\
\text { skull, and focal neurological } \\
\text { symptom. ICD-10 codes: S02 } \\
\text { without S02.5, S04, S06-S07, } \\
\text { S09. }\end{array}$ & $\begin{array}{r}\text { GCS: } 90.2 \% \text { mild, } 3.9 \% \\
\text { moderate, } 5.2 \% \text { severe }\end{array}$ & $332 / 105$ \\
\hline $\begin{array}{l}\text { Rosso et al. } \\
\quad(2007) \\
{[29]}\end{array}$ & $\begin{array}{l}\text { Patients admitted to one of the five } \\
\text { Austrian hospitals. }\end{array}$ & $\begin{array}{l}\text { Glasgow Coma Scale (GCS) score } \\
\text { of } 8 \text { or less following } \\
\text { resuscitation, which may include } \\
\text { endotracheal intubation; or GCS } \\
\text { score deteriorating to } 8 \text { or less } \\
\text { within } 48 \text { h of injury. }\end{array}$ & GCS: $100 \%$ severe & Not reported \\
\hline $\begin{array}{l}\text { Scholten } \\
\text { et al. } \\
\text { (2014) } \\
{[30]}\end{array}$ & $\begin{array}{l}\text { All patients with TBI treated at an } \\
\text { ED and/or admitted to hospital in } \\
\text { The Netherlands in the period } \\
2010-2012 \text {. TBI cases were } \\
\text { extracted from the Dutch Injury } \\
\text { Surveillance System (LIS) and } \\
\text { the National Hospital Discharge } \\
\text { Registry (LMR). LIS is based } \\
\text { upon the registration of } 13 \\
\text { hospitals in The Netherlands (12- } \\
15 \% \text { coverage). }\end{array}$ & $\begin{array}{l}\text { For patients treated at the } \\
\text { emergency department, TBI was } \\
\text { defined as having a 'concussion' } \\
\text { or 'other skull-brain injury' in at } \\
\text { least one of the three injuries that } \\
\text { can be recorded in LIS. For } \\
\text { hospitalised patients, TBI was } \\
\text { defined using ICD-9 codes: } 850 \text {, } \\
\text { 800-801, 803, 804, 851-854, 905, } \\
\text { 907, 950, 959. }\end{array}$ & Not reported & $213.6 / 105$ \\
\hline $\begin{array}{l}\text { Servadei } \\
\text { et al. } \\
\quad(2002) \\
{[31]}\end{array}$ & $\begin{array}{l}\text { Patients admitted to any one of the } 7 \\
\text { hospitals in Romagna plus pre- } \\
\text { and in-hospital deaths. }\end{array}$ & $\begin{array}{l}\text { ICD-9 codes: } 800.0-800.3,801.0- \\
\text { 801.3, 803.0-803.3, 850, 851.0- } \\
\text { 851.1, 852.0-852.1, 853.0-853.1, } \\
\text { 854.0-854.1 with physician } \\
\text { diagnosed TBI. Emergency } \\
\text { department patients treated and } \\
\text { released were excluded. }\end{array}$ & ICD-9 codes: $81 \%$ mild & $\begin{array}{l}250 / 10581 \% \text { were } \\
\text { mild }\end{array}$ \\
\hline $\begin{array}{l}\text { Servadei } \\
\quad \text { et al. } \\
\quad(2002) \\
{[32]}\end{array}$ & $\begin{array}{l}\text { Medical records of hospital } \\
\text { admissions for head injury. }\end{array}$ & $\begin{array}{l}\text { ICD-9 codes: } 800.0-800.3,801.0- \\
\quad 801.3,803.0-803.3,850,851.0- \\
\text { 851.1, 852.0-852.1, 853.0-853.1, } \\
\text { 854.0-854.1. }\end{array}$ & Not reported & $\begin{array}{l}314 / 105 \text { (overall) } 322 / \\
105 \text { (Trentino) 297/ } \\
105 \text { (Romagna) }\end{array}$ \\
\hline $\begin{array}{l}\text { Shivaji et al. } \\
\qquad(2014) \\
{[33]}\end{array}$ & $\begin{array}{l}\text { Data from Scottish Morbidity } \\
\text { Record (SMR01) data-set. } \\
\text { SMR01 includes all inpatients } \\
\text { and day cases discharged from } \\
\text { hospitals across Scotland. }\end{array}$ & $\begin{array}{l}\text { ICD-10 codes: S01.0, S01.9, S02.0, } \\
\text { S02.1, S02.3, S02.7, S02.9, } \\
\text { S04.0, S06.0, S06.9, S07.0, } \\
\text { S07.1, S07.8, S07.9, S09.7, } \\
\text { S09.9, T01.0, T02.0, T04.0, } \\
\text { T06.0, T90.1, T90.2, T90.4, } \\
\text { T90.5, T90.8, T90.9 }\end{array}$ & Not reported & $\begin{array}{l}\text { 446.4/105 (men) } \\
194.8 / 105 \text { (women) }\end{array}$ \\
\hline $\begin{array}{l}\text { Steudel et al. } \\
\qquad(2005) \\
{[34]}\end{array}$ & $\begin{array}{l}\text { Federal Bureau of Statistics, } \\
\text { hospital admissions register and } \\
\text { mortality register. }\end{array}$ & $\begin{array}{l}\text { ICD 9th }=800-804,850-854 ; \text { ICD } \\
\text { 10th }=\text { S02.0-S02.9 and S06.0- } \\
\text { S06.9. }\end{array}$ & ICD-9 codes: $72 \%$ mild & $337 / 105(1998)$ \\
\hline $\begin{array}{l}\text { Stocchetti } \\
\quad \text { et al. } \\
(2012) \\
{[35]}\end{array}$ & Admission to neurosurgical ICUs. & $\begin{array}{l}\text { Admission because of head trauma, } \\
\text { with or without extracranial } \\
\text { injuries; brain injury severity } \\
\text { requiring admission to ICU; time } \\
\text { trauma-arrival }<24 \text { h; age over } 18 \\
\text { years. Brain injury not further } \\
\text { defined. }\end{array}$ & Not reported & Not reported \\
\hline $\begin{array}{l}\text { Styrke et al. } \\
\quad(2007) \\
{[36]}\end{array}$ & $\begin{array}{l}\text { Data set from the Umeå University } \\
\text { Hospital's injury register. }\end{array}$ & $\begin{array}{l}\text { ICD numbers for brain injuries } \\
\text { included are within S06, also the } \\
\text { 'unspecified' ICD codes were } \\
\text { scrutinised to find 'hidden' cases. }\end{array}$ & $\begin{array}{l}\text { GCS: } 97 \% \text { mild, } 1 \% \text { moderate, } \\
2 \% \text { severe }\end{array}$ & $354 / 105$ \\
\hline
\end{tabular}


Table 2 (continued)

\begin{tabular}{lllll}
\hline Reference & $\begin{array}{l}\text { Inclusion criteria and case } \\
\text { ascertainment }\end{array}$ & Case definitions & TBI severity & Incidence rate/year \\
\hline $\begin{array}{l}\text { Szarpak \& } \\
\begin{array}{l}\text { Madziala } \\
(2011)\end{array}\end{array}$ & $\begin{array}{c}\text { Based on the emergency } \\
\text { intervention cards of Emergency } \\
{[37]}\end{array}$ & $\begin{array}{c}\text { Medical Service teams. } \\
\text { Concussion, open head wound, } \\
\text { integument contusion, skull } \\
\text { fracture. }\end{array}$ & $\begin{array}{c}\text { GCS: } 81 \% \text { mild, } 10 \% \text { moderate, } \\
9 \% \text { serious }\end{array}$ & Not reported \\
\hline
\end{tabular}

the GCS. Other tools that were used to define TBI, were Head Injury Severity Scale (HISS), Abbreviated Injury Scale (AIS) or clinical symptoms. Twenty-one out of 28 studies provided information on the severity distribution of TBI. The severity of TBI was measured by the GCS score in 12 out of these 21 studies. Other methods that have been used to measure the TBI severity were AIS head score, HISS score, or ICD codes. Eight out of 21 studies focused on severe or moderate-to-severe TBIs. In studies that provide complete information on all TBI severities $(n=12 ;[2,3,5$, $7,10,12,24,27,31,34,36,37])$, we see that the percentage of mild TBIs varies between $71 \%$ [24] and $97.5 \%$ [3].

These differences make it difficult to compare the incidence. Six out of 28 studies did not report an incidence rate. Out of the remaining 22 studies, five focused on severe or moderate-to-severe TBI [1, 18-20, 26]. The other 17 studies focused on patients with all TBI severities. The incidences of these 17 studies displayed a large variation: Pérez et al. (2011) [25] reported an incidence rate of 47.3 per $10^{5}$ population per year in Spain in 2000-2009, while Andersson et al. (2003) [3] reported a rate of 546 per $10^{5}$ population per year in Western Sweden in 1992-1993. Including only the studies that focus on patients with severe TBI $(n=4)$, a range of incidence is reported from 4.1 per $10^{5}$ population in Norway [1] to 17.3 per $10^{5}$ population in Aquitaine, France [19]. Fig. 2 illustrates this wide variation of reported incidence rates. We note that studies concentrating on severe TBI $[1,18-20]$ cluster to the left (low incidence) and those including all injuries to the right (higher incidence).

A meta-analysis of the 17 studies focusing on patients with all TBI severities was performed. Figure 3 shows the large variation of these incidences and a substantial degree of heterogeneity was confirmed on statistical evaluation $\left(I^{2}=99.9 \% ; Z=6.687\right)$. An overall incidence rate of 262 (CI, 185-339) per 100,000 per year for admitted TBI patients was derived.

\section{Epidemiological patterns: age, sex and cause of TBI}

Table 3 presents demographic data of the study populations. In assessing the age distribution, we must note that some studies only include adults in their study population. With this caveat in mind, we see that, in general, TBI is more prevalent among people aged $<25$ years and among people $>75$ years. In three studies $[14,18,26]$ an increase is seen in the elderly percentile or the mean age over the years of the study.

Mean age varies strongly: Styrke et al. (2007) [36] reported a mean age of 22 years, while Mauritz et al. (2008) [22] reported a mean age of 49 years. The latter study, however, included only severe TBI cases. The variation in mean age probably reflects different case ascertainment and inclusion criteria. In most cases, the mean age in females was higher than the mean age in males.

In all 28 studies, there was a male predominance: the maleto-female ratio ranged from 1.2:1.0 [24] to 4.6:1.0 [22].

In 13 out of 26 studies that provided data on the mechanisms of injury, falls were the most frequent cause of TBI. Road traffic accidents (RTAs) were reported as the most frequent cause of TBI in 11 studies. Table 4 shows the most frequent causes of TBI in the study period and TBI severity. In 8 out of 13 studies that include data from before 2000, RTAs are reported as the main cause of TBI. Falls were dominant in the remaining five studies. Only 2 out of 12 studies that include solely data from 2000 or later report RTA as the main cause of the brain injury. In eight studies, falls were dominant. Thus, over time a clear shift can be seen in terms of leading cause of TBI, namely from RTAs to falls.

Within the studies that focus mainly on more severe TBI, RTA as a cause of injury remains dominant. In this category of studies (moderate-to-severe and severe TBI only), RTA remains the leading cause in six out of eight studies.

A clear correlation was also found between age and mechanism of injury. Falls are most common in two age groups: the elderly and children. In contrast, RTAs are the most frequent cause in the age group of young adults. Also notable is the geographical spread of the mechanisms of injury: Scandinavian countries reported mainly falls, while other countries reported more RTAs.

\section{Mortality rate and case fatality rate}

Nine studies reported data on mortality rates (ESM 2). As with the incidence rates, a large variation was found in the mortality rates: from 3.0 per $10^{5}$ inhabitants per year in Hannover and Münster (Germany) [27] to 18.3 per $10^{5}$ inhabitants per year in Finland and Romagna (Italy) [14, 31]. This variation can 


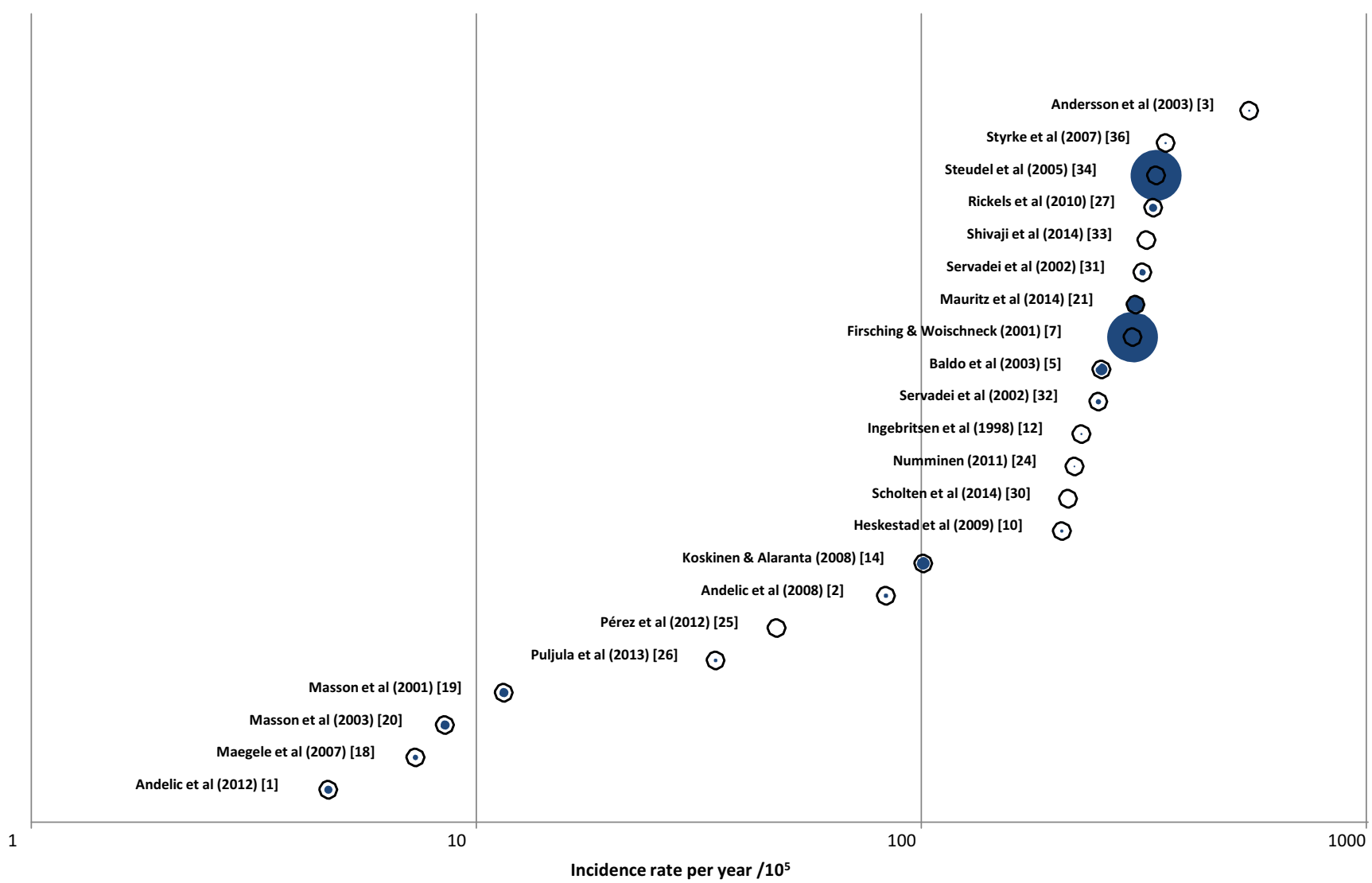

Fig. 2 Reported incidence rates for TBI. Rates are expressed per 100,000 population. Each study is marked by an open circle; the size of the blue centre is proportional to the size of the population under study

largely be explained by differences in case ascertainment and case definitions. Overall, an average mortality rate of 10.5/ 100,000 was calculated, but interpretation should be with caution due to the heterogeneity of studies.

The case fatality rate (CFR) expresses diseasespecific mortality (e.g. TBI). However, the specificity of the rate is influenced by the inclusion of patients who have died from systemic injuries or non-brain comorbidity. Distinction is made between in-hospital CFR (only in-hospital deaths) and overall CFR (in-hospital and out-of-hospital deaths). CFR is highly dependent on the severity of TBI and age of TBI patients: CFR of TBI in general ranges from 0.9 per 100 patients to 7.6 per 100 patients, while CFR of severe TBI ranges from 29 to 55 per 100 patients. None of the included studies provide information on the difference between CFR in mild TBI compared to severe TBI.

\footnotetext{
${ }^{1}$ CDEs contain all essential data elements for use across the broad spectrum of TBI. Related elements were combined in modules, which were grouped together in categories. For example, the data elements 'age, gender and race' are combined in the module 'demographics' under the category 'subject characteristics'.
}

\section{Discussion}

In recent decades, substantial research has been conducted on the epidemiology of TBI in Europe. However, a full profit cannot be taken of this potential because data have not been collected in a uniform way [16]. This review illustrates the great variability, previously reported by Maas et al. (2011) [16], that exists in data collection and coding of variables in TBI studies. Differences in case ascertainment and case definition confound comparisons between and analysis across different studies. A general consensus on choice and coding of variables for TBI studies is needed in order to acquire the exact epidemiological evolution of TBI. This is currently facilitated by the (common data elements, $\mathrm{CDEs}^{1}$ ) In context of the epidemiology, the following categories are of great importance: participant/subject characteristics; participant and family history; injury/disease related events. In general, many reports have focused on participant/subject characteristics, but fewer on the other two categories. The CDEs represent a major advance towards standardisation, which is highly relevant both from a scientific point of view and from the perspective of cost-efficiency, as this will obviate repeated development of case report forms for new studies [16]. 


\begin{tabular}{lrrr} 
Study name & & \multicolumn{2}{c}{ Statistics for each study } \\
\cline { 3 - 4 } & & Lower & Upper \\
& Rate & limit & limit \\
Ingebritsen et al (1998) [12] & 229,0 & 200,5 & 257,5 \\
Firsching \& Woischneck (2001) [7] & 350,0 & 348,7 & 351,3 \\
Servadei et al (2002) [31] & 250,0 & 240,0 & 260,0 \\
Servadei et al (2002) [32] & 314,0 & 304,8 & 323,2 \\
Andersson et al (2003) [3] & 546,0 & 507,0 & 585,0 \\
Baldo et al (2003) [5] & 247,0 & 236,7 & 257,3 \\
Steudel et al (2005) [34] & 337,0 & 335,7 & 338,3 \\
Styrke et al (2007) [36] & 354,0 & 322,5 & 385,5 \\
Andelic et al (2008) [2] & 83,3 & 75,6 & 91,0 \\
Koskinen \& Alaranta (2008) [14] & 101,3 & 90,6 & 112,0 \\
Heskestad et al (2009) [10] & 207,0 & 190,2 & 223,8 \\
Numminen (2011) [24] & 221,0 & 176,0 & 266,0 \\
Rickels et al (2010) [27] & 332,0 & 324,4 & 339,6 \\
Pérez et al (2012) [25] & 47,3 & 45,3 & 49,3 \\
Mauritz et al (2014) [21] & 303,0 & 296,6 & 309,4 \\
Scholten et al (2014) [30] & 213,6 & 193,1 & 234,1 \\
Shivaji et al (2014) [33] & 321,7 & 305,1 & 338,3 \\
Overall incidence & $\mathbf{2 6 1 , 9}$ & 198,5 & $\mathbf{3 2 5 , 2}$
\end{tabular}

Rate and $95 \% \mathrm{Cl}$

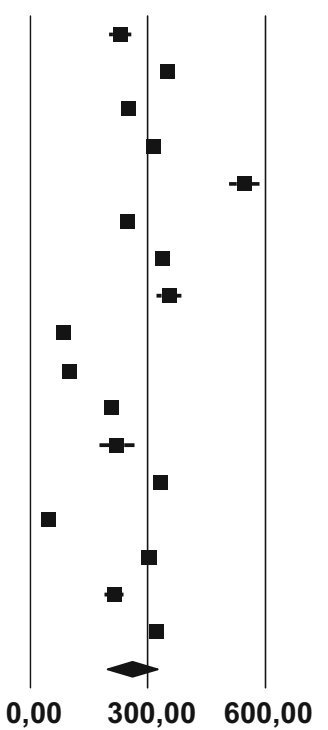

Fig. 3 Forest plot of incidence rate per study sorted by year of publication. The forest plot represents the meta-analysis on 17 studies focusing on patients with all TBI severities. A random effects model was applied. Incidence rates are denoted by the black boxes and the
$95 \%$ CIs by the horizontal lines. The overall incidence rate is represented by the black diamond, where the diamond width correspondents to the $95 \%$ CIs. Heterogeneity is substantial: $\tau^{2}=17650.3 ; \chi^{2}=72801.5, d f=16(p=0.000) ; I^{2}=99.9 \%$
Variability in case definitions and case ascertainment does not directly influence the methodological quality of individual studies. However, 9 of the 28 studies included in the review did not meet the quality criteria of the five selected elements of the STROBE checklist. We chose to evaluate the methodological quality of the studies included according to a pre-specified checklist with specific criteria, rather than allocating a subjective judgment. We considered the STROBE checklist [39] as the most appropriate tool, and selected five criteria of this checklist as being most relevant to the evaluation of epidemiological studies. However, despite the use of this checklist and pre-defined criteria, an element of subjective assessment remains. Tables 1 and 3 illustrate the need for improvement of methodological quality, as well as a great need for standardisation of studies and their reporting.

Unlike Tagliaferri et al. [38], who reported an average incidence and mortality rate in their review, we used the random effects model of meta-analysis to calculate an overall incidence rate. This model is better suited for the comparison of studies with a large heterogeneity. Based on the random effects model of meta-analysis, we found an overall incidence rate of 262 per 100,000 per year. For sake of comparison, we also calculated a simple average incidence rate. This average incidence rate (only including the 17 studies focusing on patients with all TBI severities) was about 275 per 100,000 population per year. After excluding the aberrant rates from Spain
[25] and Western Sweden [3], the average rate was 326 per 100,000 population per year. This estimate differs greatly from the incidence rate of 235 per $10^{5}$ population per year reported by Tagliaferri et al. [38] in 2006. This could indicate an increase in incidence of TBI in the past decade or an underregistration of TBI in period 1980-1990. The latter is the most likely explanation in high income countries, while an increase in true incidence of TBI has been described for middle and low-income countries [17].

It remains, however, difficult to calculate an average incidence and mortality rate since great variation can be found in the case definitions, inclusion criteria and methods used in the studies. For example, studies that are based on hospital and emergency department admissions will report a higher incidence rate than studies that are only based on one of these two. For this reason, it is important to interpret the average rates in a critical manner. For morality, we calculated an average rate of 10.53 per $10^{5}$ per year. This rate is lower than the mortality rate of 15.4 found by Tagliaferri et al. [38] in 2006. Interpretation of this decrease should, however, be viewed with great caution, given the heterogeneity between studies and absence of possibilities to adjust for case mix. Table 5 shows a comparison between the review of Tagliaferri et al. [38] and the current review.

More definitive conclusions can be drawn on changing epidemiological patterns. In most of the studies, a peak is seen 
Table 3 Epidemiological patterns: age and sex

\begin{tabular}{|c|c|c|}
\hline Reference & Mean age & $\begin{array}{l}\text { Male-to-female } \\
\text { ratio }\end{array}$ \\
\hline Ingebritsen et al. (1998) [12] & - & $1.7: 1.0$ \\
\hline Masson et al. (2001) [19] & $\begin{array}{l}\text { AIS head 4: } 44 \text { years } \\
\text { AIS head 5: } 45 \text { years }\end{array}$ & 2.5:1.0 \\
\hline $\begin{array}{l}\text { Firshing \& Woischneck } \\
\text { (2001) [7] }\end{array}$ & 39 years & $2.45: 1.0$ \\
\hline Servadei et al. (2002) [31] & - & $1.6: 1.0$ \\
\hline Servadei et al. (2002) [32] & - & $\begin{array}{l}\text { Romagna: } \\
\text { 1.6:1.0 } \\
\text { Trentino: 1.8:1.0 }\end{array}$ \\
\hline Masson et al. (2003) [20] & 41 years & $3.1: 1.0$ \\
\hline Baldo et al. (2003) [5] & $\begin{array}{l}\text { Male, } 37.7 \text { years } \\
\text { Female, } 45.6 \text { years. }\end{array}$ & $1.55: 1.0$ \\
\hline Andersson et al. (2003) [3] & Age, 27 years & $1.46: 1.0$ \\
\hline Steudel et al. (2005) [34] & - & Not reported \\
\hline Styrke et al. (2007) [36] & $\begin{array}{l}\text { Male, } 23 \text { years } \\
\text { Female, } 22 \text { years }\end{array}$ & $1.2: 1.0$ \\
\hline Rosso et al. (2007) [29] & 48.2 years & $\begin{array}{l}\text { Overall: } 2.6: 1.0 \\
\text { Salzburg: } 1.5: 1.0\end{array}$ \\
\hline Maegele et al. (2007) [18] & 40.3 years & $2.7: 1.0$ \\
\hline $\begin{array}{l}\text { Koskinen \& Alaranta (2008) } \\
\text { [14] }\end{array}$ & $1.4-1.5: 1.0$ & \\
\hline Mauritz et al. (2008) [22] & 49 years & $\begin{array}{l}\text { HI: } 2.6: 1.0 \\
\text { UMI: 4.6:1.0 } \\
\text { LMI: 3.5:1.0 }\end{array}$ \\
\hline Andelic et al. (2008) [2] & 29 years. Male, 29 years. Female, 27 years & $1.8: 1.0$ \\
\hline Heskestad et al. (2009) [10] & - & $1.7: 1.0$ \\
\hline Rickels et al. (2010) [27] & - & $1.4: 1.0$ \\
\hline Numminen (2011) [24] & - & $1.2: 1.0$ \\
\hline $\begin{array}{l}\text { Katsaragakis et al. (2010) } \\
\text { [13] }\end{array}$ & - & 2.6:1.0 \\
\hline $\begin{array}{l}\text { Szarpak \& Madziala (2011) } \\
\text { [37] }\end{array}$ & $\begin{array}{l}42 \text { years } \\
\text { Male, } 39 \text { years } \\
\text { Female, } 47 \text { years }\end{array}$ & $1.9: 1.0$ \\
\hline Pérez et al. (2012) [25] & - & $\begin{array}{c}\text { RTA: } 2.7: 1.0 \\
\text { Other injury: } \\
1.7: 1.0\end{array}$ \\
\hline Stocchetti et al. (2012) [35] & 45 years & $2.85: 1.0$ \\
\hline Andelic et al. (2012) [1] & $\begin{array}{l}46.7 \text { years } \\
\text { Male, } 44.8 \text { years } \\
\text { Female, } 53.2 \text { years }\end{array}$ & 3.35: 1.0 \\
\hline Mauritz et al. (2014) [21] & $\begin{array}{l}44.5 \text { years } \\
\text { Male, } 40.9 \text { years; female, } 49.9 \text { years } \\
\text { Outpatients: male, } 35.8 \text { years; female, } 38.6 \text { years } \\
\text { In-hospital deaths: } 65.9 \text { years; male, } 62.5 \text { years; female, } 73.5 \text { years }\end{array}$ & $1.4: 1.0$ \\
\hline Puljula et al. (2013) [26] & $\begin{array}{l}\text { In 1999: overall, } 44 \text { years; male, } 41 \text { years; female, } 52 \text { years. In 2007: overall, } 48 \text { years; male, } \\
46 \text { years; female, } 55 \text { years }\end{array}$ & $\begin{array}{l}\text { 1999: } 2.6: 1.0 \\
\text { 2007: } 3.2: 1.0\end{array}$ \\
\hline Scholten et al. (2014) [30] & - & $1.35: 1.0$ \\
\hline Shivaji et al. (2014) [33] & - & $2.29: 1.0$ \\
\hline
\end{tabular}


Table 4 Most frequent cause of TBI in the study period and TBI severity

\begin{tabular}{|c|c|c|c|}
\hline Reference & TBI severity & Study period & Most frequent cause of TBI \\
\hline Maegele et al. (2007) [18] & Severe & 1990-1999 & RTAs $(55.3 \%)$ \\
\hline Koskinen \& Alaranta (2008) [14] & All & $1991-2005$ & Falls $(51.8 \%)$ \\
\hline Andersson et al. (2003) [3] & All & 1992-1993 & $\begin{array}{l}\text { Falls (fall from height } 27.2 \% \text {; } \\
\quad \text { fall same level } 30.88 \% \text { ) }\end{array}$ \\
\hline Ingebritsen et al. (1998) [12] & All & 1993 & Falls $(62 \%)$ \\
\hline Firsching \& Woischneck (2001) [7] & All & 1996 & RTAs $(56 \%)$ \\
\hline Servadei et al. (2002) [32] & All & 1996 & RTAs (48 \%) \\
\hline Masson et al. (2001) [19] & Severe & 1996 & RTAs (48.3 \%) \\
\hline Masson et al. (2003) [20] & Severe & 1996 & RTAs (58.9 \%) \\
\hline Stocchetti et al. (2012) [35] & - & $1997-2007$ & - \\
\hline Baldo et al. (2003) [5] & All & $1996-2000$ & RTAs (49 \%) \\
\hline Servadei et al. (2002) [31] & All & 1998 & RTA (48 \%) \\
\hline Steudel et al. (2005) [34] & All & 1998 & - \\
\hline Shivaji et al. (2014) [33] & All & 1998-2009 & Falls (47 \%) \\
\hline Puljula et al. (2013) [26] & Moderate-to-severe & $1999 \& 2007$ & Falls (1999: $33 \%$; 2007: $50 \%$ ) \\
\hline Rosso et al. (2007) [29] & Severe & 1999-2004 & RTA $(44 \%)$ \\
\hline Rickels et al. (2010) [27] & All & $2000-2001$ & Falls $(52.5 \%)$ \\
\hline Pérez et al. (2012) [25] & All & $2000-2009$ & - \\
\hline Styrke et al. (2007) [36] & All & 2001 & Falls (55 \%) \\
\hline Mauritz et al. (2008) [22] & Severe & $2001-2005$ & RTAs (41\%) \\
\hline Numminen (2011) [24] & All & 2002-2004 & Falls $(58.4 \%)$ \\
\hline Heskestad et al. (2009) [10] & All & 2003 & Falls $(51 \%)$ \\
\hline Andelic et al. (2008) [2] & All & 2005-2006 & Falls $(51 \%)$ \\
\hline Andriessen et al. (2011) [4] & Moderate-to-severe & 2008-2009 & RTA $(50 \%)$ \\
\hline Szarpak \& Madziala (2011) [37] & All & 2009 & Falls $(29 \%)$ \\
\hline Andelic et al. (2012) [1] & Severe & 2009-2010 & Falls $(51 \%)$ \\
\hline Mauritz et al. (2014) [21] & All & 2009-2011 & Falls $(16.7 \%)$ \\
\hline Scholten et al. (2014) [30] & All & 2010-2012 & - \\
\hline Katsaragakis et al. (2010) [13] & - & - & RTAs (54.1\%) \\
\hline
\end{tabular}

in the oldest age groups. Some studies even report an evolution of the mean age over the years. These findings confirm the shift, reported by Roozenbeek et al. (2013) [28], towards older age groups over recent decades, especially in high- income countries. In contrast to Tagliaferri et al. [38], who reported RTA as the most common event leading to TBI, we find falls to be the leading cause. Table 4 clearly shows the shift over time from RTAs to falls as the leading cause of TBI.

Table 5 Comparison with review of Tagliaferri et al. 2006 [38]

\begin{tabular}{|c|c|c|}
\hline & Tagliaferri et al. 2006 [38] & This review \\
\hline Time period of included studies & $1980-2003$ & $1990-2014$ \\
\hline Number of included studies & 23 & $28\left(9^{\mathrm{a}}\right)$ \\
\hline Number of countries & 12 & 16 \\
\hline Average incidence rate per $10^{5} /$ year & 235 & 326 \\
\hline Overall incidence rate per $10^{5} /$ year $^{\mathrm{b}}$ & - & 262 \\
\hline Most frequent cause of TBI (number of studies) & RTAs (8)> falls (6) & Falls (14) $>$ RTAs (11) \\
\hline Sex & Male $>$ female & Male $>$ female \\
\hline Average mortality rate per $10^{5} /$ year & 15 & 10,5 \\
\hline
\end{tabular}

${ }^{\text {a }}$ Nine studies overlap with the review by Tagliaferri et al. 2006 [38]

${ }^{\mathrm{b}}$ Overall incidence derived from random effects modelling 
RTA still remains the most frequent cause in the group of severe TBI. However, an interaction may exist with study period as most of the studies on severe TBI contain data from before 2000 .

Falls are thus becoming a more and more important cause of TBI, mainly in the high-income regions of Europe. An additional finding is the strong correlation between age groups and mechanism of injury. In the majority of the studies, we found that falls are more common in the youngest and oldest age group. On the other hand, we found that RTAs are most common in young adults. These differences have important implications for targeting prevention campaigns.

\section{Strengths and limitations}

We used clear search terms and conducted a thorough and systematic literature search. We attempted to include all the relevant articles and to display the study characteristics and results in a clear manner. However, we should note that some studies may have been missed, e.g. if they did not meet the search terms or were not included in PubMed. The major limitations are inherent to the studies underpinning this review and mainly relate to the differences in case ascertainment and case definitions. Although we used the random effects model of meta-analysis to derive an overall incidence rate, the large degree of heterogeneity identified implies that interpretation should be with caution.

\section{Conclusions}

This review does not show any trend towards a decreasing incidence of TBI in Europe. The average mortality rate appears lower than in a previous review. Interpretation of data should, however, be with caution, given existing heterogeneity between reports and major differences in approaches to definitions and case ascertainment. In 2006, Tagliaferri et al. [38] identified a need for high-quality epidemiological studies and collaborative intra-European Union population-based studies. Our review confirms the need for generalised/ standardised case definitions, case ascertainment and study methods. We further identify changes in epidemiological patterns with increasing age and identify falls as currently the most common cause of TBI in Europe. This has changed compared with previous studies in which RTAs were the more dominant cause. These changes in epidemiological patterns should inform better targeting of prevention campaigns.

Acknowledgments The work of S.P., A.B.., E.S., H.L. and A.M. was partly funded by the European Union Framework 7 program (grant 602150) in the context of the CENTER-TBI project, a large scale collaborative project embedded within the framework of the International initiative on TBI research.

Conflict of interest None.

Open Access This article is distributed under the terms of the Creative Commons Attribution 4.0 International License (http:// creativecommons.org/licenses/by/4.0/), which permits unrestricted use, distribution, and reproduction in any medium, provided you give appropriate credit to the original author(s) and the source, provide a link to the Creative Commons license, and indicate if changes were made.

\section{References}

1. Andelic N, Anke A, Skandsen T, Sigurdardottir S, Sandhaug M, Ader T, Roe C (2012) Incidence of hospital-admitted severe traumatic brain injury and in-hospital fatality in Norway: a national cohort study. Neuroepidemiology 38:259-267

2. Andelic N, Sigurdardottir S, Brunborg C, Roe C (2008) Incidence of hospital-treated traumatic brain injury in the Oslo population. Neuroepidemiology 30:120-128

3. Andersson EH, Bjorklund R, Emanuelson I, Stalhammar D (2003) Epidemiology of traumatic brain injury: a population based study in western Sweden. Acta Neurol Scand 107:256-259

4. Andriessen TM, Horn J, Franschman G, van der Naalt J, Haitsma I, Jacobs B, Steyerberg EW, Vos PE (2011) Epidemiology, severity classification, and outcome of moderate and severe traumatic brain injury: a prospective multicenter study. J Neurotrauma 28:20192031

5. Baldo V, Marcolongo A, Floreani A, Majori S, Cristofolettil M, Dal Zotto A, Vazzoler G, Trivello R (2003) Epidemiological aspect of traumatic brain injury in Northeast Italy. Eur J Epidemiol 18:10591063

6. Cole TB (2004) Global road safety crisis remedy sought: 1.2 million killed, 50 million injured annually. JAMA 291:2531-2532

7. Firsching R, Woischneck D (2001) Present status of neurosurgical trauma in Germany. World J Surg 25:1221-1223

8. Gerber LM, Chiu YL, Carney N, Hartl R, Ghajar J (2013) Marked reduction in mortality in patients with severe traumatic brain injury. J Neurosurg 119:1583-1590

9. Ghajar J (2000) Traumatic brain injury. Lancet 356:923-929

10. Heskestad B, Baardsen R, Helseth E, Romner B, Waterloo K, Ingebrigtsen T (2009) Incidence of hospital referred head injuries in Norway: a population based survey from the Stavanger region. Scand J Trauma Resusc Emerg Med 17:6

11. Higgins JP, Thompson SG, Deeks JJ, Altman DG (2003) Measuring inconsistency in meta-analyses. BMJ 327:557-560

12. Ingebrigtsen T, Mortensen K, Romner B (1998) The epidemiology of hospital-referred head injury in Northern Norway. Neuroepidemiology 17:139-146

13. Katsaragakis S, Drimousis PG, Toutouzas K, Stefanatou M, Larentzakis A, Theodoraki ME, Stergiopoulos S, Theodorou D (2010) Traumatic brain injury in Greece: report of a countrywide registry. Brain Inj 24:871-876

14. Koskinen S, Alaranta H (2008) Traumatic brain injury in Finland 1991-2005: a nationwide register study of hospitalized and fatal TBI. Brain Inj 22:205-214

15. Lu J, Marmarou A, Choi S, Maas A, Murray G, Steyerberg EW, Impact, Abic Study G (2005) Mortality from traumatic brain injury. Acta Neurochir 95:281-285 
16. Maas AI, Harrison-Felix CL, Menon D, Adelson PD, Balkin T, Bullock R, Engel DC, Gordon W, Langlois-Orman J, Lew HL, Robertson C, Temkin N, Valadka A, Verfaellie M, Wainwright M, Wright DW, Schwab K (2011) Standardizing data collection in traumatic brain injury. J Neurotrauma 28:177-187

17. Maas AI, Stocchetti N, Bullock R (2008) Moderate and severe traumatic brain injury in adults. Lancet Neurol 7:728-741

18. Maegele M, Engel D, Bouillon B, Lefering R, Fach H, Raum M, Buchheister B, Schaefer U, Klug N, Neugebauer E (2007) Incidence and outcome of traumatic brain injury in an urban area in Western Europe over 10 years. Eur Surg Res 39:372-379

19. Masson F, Thicoipe M, Aye P, Mokni T, Senjean P, Schmitt V, Dessalles PH, Cazaugade M, Labadens P (2001) Epidemiology of severe brain injuries: a prospective population-based study. $\mathrm{J}$ Trauma 51:481-489

20. Masson F, Thicoipe M, Mokni T, Aye P, Erny P, Dabadie P (2003) Epidemiology of traumatic comas: a prospective population-based study. Brain Inj 17:279-293

21. Mauritz W, Brazinova A, Majdan M, Leitgeb J (2014) Epidemiology of traumatic brain injury in Austria. Wien Klin Wochenschr 126:42-52

22. Mauritz W, Wilbacher I, Majdan M, Leitgeb J, Janciak I, Brazinova A, Rusnak M (2008) Epidemiology, treatment and outcome of patients after severe traumatic brain injury in European regions with different economic status. Eur J Public Health 18:575-580

23. Menon DK, Schwab K, Wright DW, Maas AI; Demographics and Clinical Assessment Working Group of the International and Interagency Initiative toward Common Data Elements for Research on Traumatic Brain Injury and Psychological Health (2010) Position statement: definition of traumatic brain injury. Arch Phys Med Rehabil 91:1637-1640

24. Numminen HJ (2011) The incidence of traumatic brain injury in an adult population - how to classify mild cases? Eur J Neurol 18:460-464

25. Perez K, Novoa AM, Santamarina-Rubio E, Narvaez Y, Arrufat V, Borrell C, Cabeza E, Cirera E, Ferrando J, Garcia-Altes A, Gonzalez-Luque JC, Lizarbe V, Martin-Cantera C, Segui-Gomez M, Suelves JM (2012) Incidence trends of traumatic spinal cord injury and traumatic brain injury in Spain, 2000-2009. Accid Anal Prev 46:37-44

26. Puljula J, Makinen E, Cygnel H, Kortelainen ML, Hillbom M (2013) Incidence of moderate-to-severe traumatic brain injuries after reduction in alcohol prices. Acta Neurol Scand 127:192-197

27. Rickels E, von Wild K, Wenzlaff P (2010) Head injury in Germany: a population-based prospective study on epidemiology, causes, treatment and outcome of all degrees of head-injury severity in two distinct areas. Brain Inj 24:1491-1504

28. Roozenbeek B, Maas AIR, Menon DK (2013) Changing patterns in the epidemiology of traumatic brain injury. Nat Rev Neurol 9:231236

29. Rosso A, Brazinova A, Janciak I, Wilbacher I, Rusnak M, Mauritz W (2007) Severe traumatic brain injury in Austria II: epidemiology of hospital admissions. Wien Klin Wochenschr 119:29-34

30. Scholten AC, Haagsma JA, Panneman MJ, van Beeck EF, Polinder S (2014) Traumatic brain injury in the Netherlands: incidence, costs and disability-adjusted life years. PLoS One 9, e110905

31. Servadei F, Antonelli V, Betti L, Chieregato A, Fainardi E, Gardini E, Giuliani G, Salizzato L, Kraus JF (2002) Regional brain injury epidemiology as the basis for planning brain injury treatment. The Romagna (Italy) experience. J Neurosurg Sci 46:111-119

32. Servadei F, Verlicchi A, Soldano F, Zanotti B, Piffer S (2002) Descriptive epidemiology of head injury in Romagna and Trentino. Comparison between two geographically different Italian regions. Neuroepidemiology 21:297-304

33. Shivaji T, Lee A, Dougall N, McMillan T, Stark C (2014) The epidemiology of hospital treated traumatic brain injury in Scotland. BMC Neurol 14:2

34. Steudel WI, Cortbus F, Schwerdtfeger K (2005) Epidemiology and prevention of fatal head injuries in Germany - trends and the impact of the reunification. Acta Neurochir (Wien) 147:231-242, discussion 242

35. Stocchetti N, Paterno R, Citerio G, Beretta L, Colombo A (2012) Traumatic brain injury in an aging population. J Neurotrauma 29: $1119-1125$

36. Styrke J, Stalnacke BM, Sojka P, Bjornstig U (2007) Traumatic brain injuries in a well-defined population: epidemiological aspects and severity. J Neurotrauma 24:1425-1436

37. Szarpak L, Madziala M (2011) Epidemiology of cranio-cerebral injuries in emergency medical services practice. Pol Przegl Chir 83:646-651

38. Tagliaferri F, Compagnone C, Korsic M, Servadei F, Kraus J (2006) A systematic review of brain injury epidemiology in Europe. Acta Neurochir (Wien) 148:255-268, discussion 268

39. Vandenbroucke JP, von Elm E, Altman DG, Gotzsche PC, Mulrow CD, Pocock SJ, Poole C, Schlesselman JJ, Egger M, Initiative S (2014) Strengthening the reporting of observational studies in epidemiology (STROBE): explanation and elaboration. Int J Surg 12: $1500-1524$ 